\title{
Informed consent and minors
}

\author{
Andrea Nicolussi
}

From 71st Congress of the Italian Society of Pediatrics. Joint National Meeting SIP, SIMGePeD, Study Group on Pediatric Ultrasound, SUP Study Group on Hypertension

Rome, Italy. 4-6 June 2015

The provision of informed consent by a patient should be the end point of a process of engagement in which one or more health practitioners have supported the patient to come to an informed decision to agree to the healthcare offered. Informed consent is a means to comply with the principle of respect for the person in a healthcare context. This act can be alternatively interpreted according to a libertarian perspective or according to a more solidaristic one [1]. According to the former perspective, informed consent is tightly linked to the idea that every person is the proprietor of their own body with which they have the absolute right to decide whatever they want done to it. This view leads to the construction of the patient physician relationship founded on a contractual basis. According to the latter perspective, respect for the person implies a special care and not, indifference, so that consent implies the due engagement of the person in the decision process as the very etymology of the word consent suggests. Respect for a person certainly means respect for his or her autonomy, but the former concept does not correspond necessarily with the latter, especially if autonomy is not interpreted within a framework of solidarity and the patient is not sufficiently mature. Otherwise respect would slide into indifference.

As for minors, the Oviedo convention prefers to use the word authorisation instead of the common expression consent on behalf of the child. In fact, authorisation relates to the concept of a third authority, such as parental responsibility, which implies a different framework than that of informed consent. This is the concept of the child's best interests as the fundamental criterion of making decisions regarding children. Since informed consent can be seen as an expression of personal choice, it can only be given by the person who is to be provided with health care. Moreover, the Oviedo convention requires that the opinion of the minor shall be taken into consideration.

Correspondence: andrea.nicolussi@unicatt.it

Università Cattolica del Sacro Cuore, Istituto Giuridico, Milan, Italy
As a result, the decision-making process involves three categories of subjects: the physician who proposes the therapy, the parents who give authorisation and the minor whose opinion "is an increasingly determining factor in proportion of his or her degree of maturity" [2-5]. Further problems can derive from the fragile condition of modernday families and the related difficulty in parents agreeing on any given issue.

Published: 30 September 2015

\section{References}

1. Nicolussi A: Testamento biologico e problemi del fine-vita: verso un bilanciamento di valori o un nuovo dogma della volontà? Europa e diritto privato 2013, 2:457-487.

2. Crocetta C: I diritti e I'autonomia decisionale del minore in ospedale. Basilea: Helbing Lichtenhanh; 2014.

3. Freeman M: Why it remains important to take children's rights seriously? The International Journal of Children's Rights 2007, 15(1):5-23.

4. Palazzani L: L'interesse del minore tra bioetica e diritto. Roma: Studium; 2010.

5. Bussani $M$, Cendon $P$, Ghedini $L$, Venchiarutti $A$ : I diritti della personalità dei minori: titolarità ed esercizio. Rivista critica di diritto privato 1990, 2:773-812.

doi:10.1186/1824-7288-41-S2-A51

Cite this article as: Nicolussi: Informed consent and minors. Italian Journal of Pediatrics 2015 41(Suppl 2):A51.

Submit your next manuscript to BioMed Central and take full advantage of:

- Convenient online submission

- Thorough peer review

- No space constraints or color figure charges

- Immediate publication on acceptance

- Inclusion in PubMed, CAS, Scopus and Google Scholar

- Research which is freely available for redistribution 